\title{
Gênero e história das mulheres na historiografia
}

História \&... gênero.

GONÇALVES, Andréa Lisly.

Belo Horizonte: Autêntica, 2006. 160 p. (História \&... reflexões, 9).

História \&... gênero faz parte das recentes e crescentes publicações que têm por objetivo os estudos de gênero, história das mulheres e atuação dos movimentos feministas. Neste livro, Andréa Lisly Gonçalves sugere uma reflexão sobre o gênero como categoria analítica, enfatizando a abordagem de caráter estritamente relacional das construções sociais do feminino e do masculino ao longo dos processos históricos, no intuito de que assim seja superada a idéia de uma suposta "condição feminina". A autora professora do Departamen-to de História da Universidade Federal de Ouro Preto (UFO) desenvolve estudos sobre identidades étnicas e revoltas sociais em Minas Gerais e não possui outras publicações, além desta, sobre gênero e história das mulheres. Contudo, já na introdução desse trabalho justifica que seu interesse pelo tema surgiu ao constatar distinções de gênero nos dados quantitativos de suas pesquisas sobre as práticas de alforrias no Brasil nos séculos XVIII e XIX. Desta forma, despertou-lhe "a importância de considerar a categoria de gênero na compreensão dos processos históricos" (p. 11).

Este livro é o nono da coleção História \&... reflexões, publicada pela editora mineira Autêntica, e, junto a mais dez publicações, segue a proposta geral da coletânea de trazer informações concisas sobre diferentes abordagens teóricas e metodológicas em relação à historiografia. Dividido em três capítulos, realiza uma breve avaliação, mas não menos instigante, sobre o desenvolvimento dos estudos de gênero e, principalmente, da história das mulheres nos estudos acadêmicos.

No primeiro capítulo, intitulado "Militância feminista", a autora se atém aos seguintes temas: a luta pelo abolicionismo e pelo sufrágio universal, a literatura feminista e a relação do trabalho com os espaços público/privado demarcados então por questões de gênero. $O$ que se destaca é que Andréa Gonçalves mostra à leitora e ao leitor como esses espaços foram permeados pelas militâncias feministas das mais variadas formas e ações durante o século XIX, seja nas manifestações abolicionistas ou por meio da escrita, como, por exemplo, nos textos de Virginia Woolf, ou seja, o objetivo dessa parte do livro é perceber como a "questão da mulher" ganhou evidência ainda no século XIX.

A autora traça, ao longo de todo o livro, paralelos comparativos entre as experiências internacionais e as situações encontradas no Brasil em relação aos estudos de gênero, história das mulheres e feminismos. Contudo, nesse primeiro capítulo, restringe-se apenas a citar a atuação de Nísia Floresta no século XIX, bem como a questão do voto das mulheres no Brasil em 1934. No mais, as comparações são realizadas, de uma forma mais geral, entre América Latina, Europa e Estados Unidos.

Além da questão da luta pelo sufrágio universal, em que a autora traz a síntese dos processos de adoção do direito ao voto para 
as mulheres em diferentes países, a questão do trabalho das mulheres, abordada em "As transformações invisíveis", ocupa a última parte do capítulo. Andréa ressalta que a organização da economia no século XIX fez com que as mulheres fossem gradativamente incorporadas aos espaços públicos por meio do trabalho, ainda que ocupassem escalões inferiores e precisassem, inicialmente, da autorização de seus maridos. Para finalizar, analisa como o "modelo vitoriano" de controle sobre as sensações e os sentimentos ajudou a difundir o arquétipo da "rainha do lar", também denominado no início do século XX de "matriarcado orçamentário". A autora defende que o trabalho doméstico, apesar de não ser remunerado, é produtivo e que muitas mulheres souberam resistir às tendências contrárias à sua emancipação mesmo que estivessem restritas ao lar.

No segundo capítulo, "Anatomia e destino", a questão central é refletir sobre a história das mulheres no campo do debate teórico-historiográfico. O texto começa com uma reflexão acerca da frase de Freud "Anatomia é destino" para tratar das postulações teóricas em relação às diferenças sexuais na construção das identidades na passagem do século XIX para o século XX. Contudo, a maior parte desse capítulo é dedicada à discussão das diferentes interpretações dadas às bipolaridades feminino/natureza e masculino/civilização, mulheres/privado e homens/público na história. A autora conecta esse debate da história das mulheres às mudanças na historiografia partindo dos Annales, passando pelas propostas do marxismo, o momento da crise dos paradigmas, até atingir a Nova História.

Segundo Andréa, a constituição da história das mulheres como campo de conhecimento histórico se processou em relação direta com a atuação do movimento feminista das décadas de 1960 e 1970, quando então surge na década de 1980 a categoria de gênero. Assim, apresenta alguns aspectos da relação entre os movimentos feministas e a história das mulheres, tomando a publicação de O segundo sexo, de Simone de Beauvoir, até chegar ao que denomina de crise do movimento feminista e da história das mulheres, com A segunda etapa, de Betty Friedan. Nesse ínterim, ressalta o surgimento dos estudos sobre a "condição feminina" e a multiplicação dos trabalhos acadêmicos sobre a história das mulheres, bem como as críticas que esses receberam.

A autora atenta para os percalços do movimento feminista e da história das mulheres durante os anos 1990, em seus processos de organização e desenvolvimento acadêmico, com os questionamentos levantados pela história social. Prova disso são algumas críticas apresentadas, como, por exemplo, de que muitas das produções historiográficas sobre as mulheres no Brasil adotaram "concepções essencialistas" sobre "a mulher", assim mesmo no singular, como ressalta a autora; outra crítica é a da impossibilidade de tratar o tema sem relacioná-lo com outras questões trazidas pela história social, principalmente no que tange à classe e à raça.

No terceiro e último capítulo, "História das mulheres: fontes, temas e abordagens", a autora parte de sua experiência docente em História Social para apresentar os aspectos metodológicos para a história das mulheres como também para os estudos de gênero, analisando criticamente produções que se utilizaram de fontes como as biografias, os manuais de etiquetas, os testamentos, os processos, os crimes, as cartas, os diários, os dados censitários etc.

A primeira ressalva é sobre as potencialidades e a variabilidade de documentos e como a consolidação do campo de estudos sobre as mulheres e as relações de gênero provocaram uma "revolução" no uso das fontes históricas. Para Andréa, com a importância dada às fontes documentais produzidas no espaço privado e com a "releitura" dos documentos ditos "oficiais", tendo em vista as mudanças na historiografia, a história das mulheres mostrou-se "como uma das mais promissoras".

A proposta central desse capítulo é apresentar uma "amostra" bibliográfica de produções historiográficas sobre a história das mulheres, em sua maioria nacionais, no intuito de destacar o que a autora defende como a "impropriedade" de se falar em uma suposta "condição feminina" inalterável ao longo da história. Os trabalhos sobre história das mulheres e de gênero estabelecem novas propostas metodológicas, e poderíamos aqui dizer que as abordagens interdisciplinares são resultados disso.

Em suas considerações finais, Andréa ressalta os desafios colocados pela história das mulheres, de gênero e feministas para a historiografia, e o reconhecimento de que o avanço das produções nem sempre correspondeu ao estabelecimento de relações entre as experiências femininas e masculinas, como pretende uma análise de gênero de caráter estritamente relacional, defendida pela autora a todo momento. 
Sua sugestão final é que haja uma "reatualização" do potencial essencialmente político e até subversivo da história das mulheres e de gênero, e que essas mulheres sejam também analisadas por uma historiografia política, econômica, militar e religiosa, segundo a autora, majoritariamente marcadas pelas atuações masculinas. Contudo, alguns trabalhos já vêm sendo realizados nessa direção, e a discussão de gênero e religiosidade, por exemplo, é tema de artigos publicados em revistas acadêmicas, possuindo inclusive um dossiê na Revisa Estudos Feministas, de 2005, e simpósios temáticos específicos nos encontros do Seminário Internacional Fazendo Gênero, entre outros. Para concluir, uma extensa e variada lista de referências bibliográficas (e podemos dizer também sugestões) sobre o assunto encerra o livro.

História \&... gênero é uma obra de leitura agradável e destinada a estudantes e profissionais da área de História, objetivando refletir principalmente sobre a inserção e o desenvolvimento da história das mulheres na historiografia desde os anos de 1960. O gênero como uma categoria analítica para a história é discutido pela autora, porém com menor destaque, diante do que se propõe o título do obra. Contudo, a riqueza do trabalho de Andréa Lisly Gonçalves reside em somar forças junto às demais publicações, que propõem essa reflexão ao ressaltar a importância das relações de gênero e a história das mulheres na análise dos processos históricos, assim como exerce o papel divulgador de uma extensa lista de produções nacionais, apresentada ao longo do livro, que possibilita a construção de uma rede de leituras sobre o tema.

Joana Vieira Borges Universidade Federal de Santa Catarina 